\title{
Ureditev področja političnih strank v Avstriji
}

\author{
UDK: 329(436)
}

\section{Mik Strmecki}

Univerza v Ljubljani, Fakulteta za upravo

mik.strmecki@fu.uni-lj.si

\section{IZVLEČEK}

Namen članka je podati kratko analizo glavnih značilnosti avstrijske ureditve področja političnih strank v primerjavi s povojno nemško ureditvijo. V Avstriji politične stranke $v$ ustavi niso posebej opredeljene, ker ustava ne vsebuje posebnega člena o njih. Za razliko od nemškega ustavnega pristopa k zadevni ureditvi, po katerem je prišlo do izrecne konstitucionalizacije političnih strank v 21. členu nemške ustave, v Avstriji do tega ni nikoli prišlo. Specifičnost avstrijske ureditve je tudi $v$ tem, da področni zakon o političnih strankah nima nobene določbe, ki bi se nanašala na notranjo organizacijo politične stranke ter nasploh ničesar ne določa glede zagotavljanja znotrajstrankarske demokracije $v$ njih. Razliko med nemško in avstrijsko ureditvijo področja političnih strank je mogoče pripisati razliki $v$ izhodišču obeh tipov demokracije.

Ključne besede: politične stranke, Avstrija, lokalne skupnosti.

\section{Uvod}

Avstrijska ureditev področja političnih strank je imela velik vpliv na ureditev v predvojni Jugoslaviji in nasploh $v$ vseh naslednicah bivše habsburške monarhije. Podobno kot pri nas tudi $v$ Avstriji politične stranke $\vee$ ustavi niso posebej opredeljene, ker ustava niti ne vsebuje posebnega člena o njih. Podobno kot je avstrijski ustavni zakon iz leta 1929 določil nezdružljivost funkcije ustavnega sodnika s funkcijo oziroma zaposlitvijo $v$ političnih strankah, tudi slovenska ustava iz leta 1991 določa, da funkcija sodnika (133. člen) ter funkcija sodnika ustavnega sodišča (166. člen) nista združljivi s funkcijami $v$ drugih državnih organih lokalnih skupnosti in $v$ organih političnih strank ter $z$ drugimi funkcijami in dejavnostmi, za katere to določa zakon. 


\section{Mik Strmecki \\ Ureditev področja političnih strank v Avstriji}

V primerjavi z nemško ureditvijo avstrijski zakon o političnih strankah ne omenja definicije političnih strank, poleg tega pa tudi nima nobene določbe, ki bi se nanašala na notranjo organizacijo, še zlasti pa ni zaslediti člena, ki bi nalagal zagotavljanje znotrajstrankarske demokracije. Povojna nemška pravna misel se je zavedala, da mora biti ustavni sistem tako izdelan, da preprečuje sleherni pojav nelegitimnih zakonov, ki omogočajo kršitve človekovih pravic ter da ustvarjanje pravne države temelji na legitimnosti zakonodaje, ki presega koncept same legalnosti, in da mora ustava odvračati nevarnost, da bi se pravna država (Rechtstaat) izrodila $\vee$ diktatorsko državo, utemeljeno na nelegitimni zakonodaji (Gesetzestaat). Z bonsko ustavo povojne Zvezne republike Nemčije je prišlo do odločilnega obrata in popolnega odmika od predvojnega weimarskega političnega sistema, utemeljenega na zgrešeni podmeni ustavnopravnega vrednostnega relativizma, ki je omogočila odpravo demokracije po demokratični poti.

Svoboda političnega združevanja naj ne bi bila podvržena omejitvam, razen če pristojna državna institucija dokaže in definira pravno podlago za omejitev in da je le-ta nujna in $v$ javnem interesu, kakor mora tudi navesti legitimni motiv za tovrsten poseg. Dejansko stanje mora namreč biti takšno, da nujno zahteva poseg države, četudi gre, objektivno gledano, za poseg $\vee$ nadvse občutljive in pereče politične svoboščine s področja združevanja, skratka gre za legitimne omejitve teh svoboščin v javnem interesu. Oblast je pri tem svojem prizadevanju pooblaščena uveljavljati relevantne zakonodajne rešitve, ki morajo zagotavljati ob vsakršni državni intervenciji do katere bi morebiti prišlo, temeljno, s pravnim redom pravne države, zagotovljeno načelo enakih možnosti vseh legitimnih udeležencev. To je ena od najpomembnejših javnih dolžnosti, ki jim je država zavezana. Država je namreč dolžna zagotavljati in ohranjati javni interes $v$ kontekstu jamčenja svobodnega, pravnega, republikanskega kakor tudi demokratičnega javnega reda, ki skupaj z ostalimi relevantnimi načeli tvori vsebino politične ureditve pravne države oziroma prav takega njenega javnega reda (ordre public de l'etat).

Cilj države naj bi bil delovati predvsem zoper totalitarne, kakor tudi pretirano strankarsko-politične kakor tudi plutokratske tendence. Slednje tendence vodijo in potiskajo družbo $v$ nekakšno mešetarjenje pri pridobivanju sredstev za delovanje političnih strank. 


\section{Splošno o pravnem položaju avstrijskih političnih strank}

Pravni položaj političnih strank $v$ Avstriji je bil vse do sredine sedemdesetih let večinoma dokaj pomanjkljivo urejen. Navzlic pomembni vlogi političnih strank pri nastanku tako prve kot sedanje druge republike, pravni položaj političnih strank še zdaleč ni odseval njihovega dejanskega pomena v pogojih moderne demokracije (Schambeck, 1991, 603). Državnopravna znanost je političnim strankam že sorazmerno kmalu začela pripisovati njihovemu dejanskemu pomenu ustrezno vlogo, kar pa ne moremo trditi za področje pozitivnopravne ureditve (Kelsen, 19), kjer so opazne določene podobnosti z weimarsko Nemčijo (Song, 1996, 110).

Zvezna avstrijska ustava iz leta 1920 je izhajala še iz zastarele koncepcije, ki se je naslanjala na tip politične stranke, ki še ni organizacija masovnega značaja in torej pravno obstaja le $v$ času volilne kampanje ter zato ob vsakokratnem koncu volilnega obdobja preneha njen pravni obstoj. Političnim strankam je kot pravna podlaga združevanja služila društvena zakonodaja iz leta 1867, ki pa je bila do društev političnega značaja očitno restriktivna (Vereinsgesetz, 134/1867). Politične stranke so se zato izogibale registraciji po citirani društveni zakonodaji, četudi so s tem tvegale, da je bila zato njihova pravna osebnost v luči veljavnega pravnega reda sporna (Kraus, 1929, 493).

Leta 1929 so bile politične stranke prvič omenjene $\vee$ zveznem ustavnem zakonu, po katerem je bila zapovedana nezdružljivosti funkcije ustavnega sodnika s funkcijo oziroma zaposlitvijo v politični stranki, kar je bilo nedvomno izraz globokega nezaupanja do političnih strank, $\vee$ obdobju bližajoče se državljanske vojne.

Po drugi svetovni vojni so takratne vodilne avstrijske politične stranke razglasile državno neodvisnost ter ponovno vzpostavile državnopravno stanje, utemeljeno na ustavi iz leta 1920 (Deklaracija o neodvisnosti, SA G BL 1945/ čl.1) .

Ponovna vzpostavitev prejšnjega državnopravnega stanja, s pomočjo pravne kontinuitete $z$ ustavo prve avstrijske republike, se je odražala tudi na položaju političnih strank. Za politične stranke so bile ponovno uveljavljene restriktivne omejitve predvojne pravne ureditve, kar pa je trajalo le do leta 1948, ko so bile odpravljene diskriminacijske določbe dotedanje društvene zakonodaje, nanašajoče se na politična društva (Vereinsgesetz-Novelle, BGB 


\section{Mik Strmecki \\ Ureditev področja političnih strank v Avstriji}

1948/251. Zakon s področja političnih strank je izšel šele leta 1975 (Gesetz ueber die Politischen Parteien, BGB 1975/13 - v nadaljevanju Partei-Gesetz) .

Avstrijski zakon o političnih strankah ne vsebuje legalne definicije politične stranke, temveč jo označuje kot sodelujoči subjekt pri tvorjenju politične volje (Kostelka, 1983, 40). Avstrijska strankarska zakonodaja namesto pojmovne definicije političnih strank podaja le opredelitev njihovih funkcij, ki jih opravljajo na področju učinkovanja v okviru oblikovanja politične volje ljudstva. Ta obširen in nejasen opis pa je še posebej značilen po tem, da ne sploh ne omenja udeležbe političnih strank na volitvah.

Volilna zakonodaja je $v$ Avstriji ostala nespremenjena navzlic izdaji zakona o političnih strankah pred četrt stoletja ter $\vee$ bistvu o političnih strankah molči, kajti volilni zakon omenja le volilne stranke, ne političnih strank. Volilni zakon zahteva, da politične stranke, ki predložijo svoje volilne kandidate $v$ okviru volilnega postopka, tudi ustanovijo posebno volilno stranko, katere pravna osebnost je različna od pravne osebnosti politične stranke same.

Politične stranke, strogo pravno gledano, se pravzaprav ne udeležujejo volitev, temveč se jih udeležujejo le volilne stranke. Po drugi strani poznajo tudi v Avstriji strankarske volilne liste, katerih nosilke so politične stranke, kar privede do tega, da se $v$ praksi volilec sploh ne zaveda, da gre $\vee$ resnici za posledično različne pravne subjekte $\vee$ obeh primerih (Raschauer, 1986, 557). V praksi so ravno politične stranke $v$ prvi vrsti udeležene $v$ vseh fazah volilnega postopka. Če torej določena politična stranka postavi volilnega kandidata za volitve, mora $\checkmark$ okviru volilnega postopka ustanoviti volilno stranko, katere pravna osebnost je različna od osebnosti same politične stranke, poleg tega pa je tudi zgolj začasnega značaja tj. traja le do konca volilnega postopka.

Avstrijski zakon o političnih strankah tudi nima nobene določbe, ki bi se nanašala na notranjo organizacijo strank, četudi politične stranke izpostavlja kot sestavni del demokratičnega ustavnega reda ter $v$ zvezi s tem poudarja njihovo svobodno ustanavljanje in delovanje, ki ne sme biti podvrženo posebnim omejitvam, veljavnim izrecno samo za politične stranke izven konteksta splošnih omejitev. Obstaja tudi prepoved delovanja oziroma ponovnega delovanja političnih strank nacionalsocialistične provenience (Partei-Gesetz).

$\mathrm{Na}$ ravni pravne regulacije je umetna in anahronistična dvojnost med volilno in politično stranko privedla do vrste normativnih nasprotij, ki neposredno razkrivajo, do kolikšne mere pravna regulacija položaja političnih strank 
zaostaja za prakso. V drugem paragrafu področnega zakona o političnih strankah je določeno, da so politične stranke $v$ parlamentu zastopane, $v$ drugem bis paragrafu pa je določeno, da politične stranke dobijo na zveznih parlamentarnih volitvah veljavne glasove, kar oboje sicer ustreza praksi, vendar nima opore $v$ pravnem redu, v kolikor ga pravilno tolmačimo $v$ smislu, da volilni zakon pozna le volilne in ne političnih strank (lbidem).

Volilne stranke namreč pravno prenehajo obstajati s koncem volilnega postopka in neobstoječemu subjektu ne more pripadati nič, torej tudi ne volilni glasovi (Oelinger, 1992, 73). Država bi morala več narediti na področju institucionalizacije političnih strank in jih vključiti v ustavni koncept ter jim dodeliti položaj, ki ga imajo v praksi.

V primerjavi z nemškim zakonom o političnih strankah avstrijski zakon s tega področja ne omenja nobenih nalog, ki bi bile le-tem naložene zaradi zagotavljanja znotrajstrankarske demokracije. Avstrijska ustavna teorija si razlaga to neskladnost z nemško ureditvijo z razliko v izhodišču obeh tipov demokracij, tj. med nemškim tipom vrednostno angažirane demokracije, ki je pripravljena braniti pravno državno vrednostno substanco te demokracije in avstrijskim tipom vrednostno nevtralne koncepcije demokracije zavezane demokratični proceduri, ki $\vee$ načelu dovoljuje odpravo demokracije po demokratični poti (Schambeck, 1991, 603). Stopnja demokratičnosti znotrajstrankarske organizacije je razvidna iz statutov posameznih političnih strank. V avstrijskem zakonu o političnih strankah tudi ni določbe, ki bi bila primerljiva s sedemnajstim paragrafom nemškega zakona o političnih strankah, ki zahteva tajnost glasovanja pri postavljanju volilnih kandidatur. Po mnenju teoretika Sickingerja v avstrijskih političnih strankah obstaja notranji strankarski demokratični deficit, zaradi katerega demokracija znotraj političnih strank ni toliko izražena kot na področju medstrankarskega tekmovanja, kjer pa je demokratičnost na zavidljivi ravni (Sickinger, 22).

\section{Ustanavljanje političnih strank}

Po prvem odstavku tretjega paragrafa avstrijskega zakona o političnih strankah je ustanavljanje političnih strank svobodno, v kolikor ni ustavnopravnih zadržkov. 


\section{Mik Strmecki \\ Ureditev področja političnih strank v Avstriji}

Dejavnost političnih strank ne sme podleči nobenim posebnim omejitvam, ki bi jih vsebovali pravni predpisi, ki bi se nanašali zgolj na njih, ampak veljajo za njih splošne omejitve iz ustave in zakona.

Po tretjem paragrafu ustavnega zakona o prepovedi političnih strank je prepovedan vsakršen poskus ohranjanja pri življenju oziroma ponovne ustanovitve po zakonu razpuščenih nacionalsocialističnih organizacij.

Prepovedano je tudi ustanavljanje združenj, katerih cilj je s pomočjo nacionalsocialistične dejavnosti in naravnanosti članstva spodnesti samostojnost in neodvisnost države oziroma motiti njen javni red in mir. To kaže, da v tem oziru avstrijska demokracija vendarle ni v celoti vrednostno nevtralna, ker vsebuje jasno ustavnopravno prepoved dejavnosti oziroma ponovne aktivacije nacionalsocialističnih organizacij.

Odločilnega pomena $v$ zvezi s problematiko instituta prepovedi organizacij z nacionalsocialističnimi programskimi cilji je $v$ vplivu, ki ga ima ta institut na načelo svobodnega ustanavljanja političnih strank. Zakonske določbe o ustanavljanju političnih strank so $v$ tolikšni meri neizdelane, da povzročajo več problemov kot rešitev spornih vprašanj.

Zakon v zvezi s tem določa le to, da morajo politične stranke objaviti svoj statut $\vee$ periodičnem časopisju. Zakon o političnih strankah določa, da morajo politične stranke statut, ki ga morajo objaviti v periodičnem časopisju, tudi deponirati pri notranjem ministrstvu kot pristojnem registracijskem upravnem organu. Statut mora vsebovati določbe o organih politične stranke, o zastopanju stranke navzven ter izčrpen seznam pravic in dolžnosti članstva. Politična stranka s predložitvijo strankarskega statuta pristojnemu upravnemu organu izrazi zahtevo po ustanovitvi pravne osebe. Upravni organ preizkusi poleg formalnih pogojev tudi vsebinski pogoj, da ne gre za domnevno protipravno delovanje. Ob izdaji negativne odločbe kot najvišja instanca odloča ustavno sodišče. Po sodbi ustavnega sodišča iz leta 1983 je bila uveljavljena interpretacija, da zakon o političnih strankah ne pooblašča registrskega organa, da bi smel zavrniti ustanovitev politične stranke zaradi nepravilnosti v zvezi s statutom, kar privede edinole do ene same praktične posledice, da $\vee$ takem slučaju pač politični stranki ni priznana pravna osebnost.

Po razlagi teorije izpred leta 1983, ki je sledila duhu izvornega koncepta zakonodajalca področnega zakona o političnih strankah ter z delno naslonitvijo na načela splošnega upravnega prava, se je notranjemu ministru priznavala 
pravica presojati vlogo za ustanovitev politične stranke s formalnega kakor tudi vsebinskega vidika, tj. tudi z vidika morebitnih podlag za izrek zakonske prepovedi ustanovitve zaradi nacionalsocialistične programske usmeritve. Po mnenju takratne teorije je ta ministrova pravica izhajala posledično iz njegove pravice zavrnitve statuta politične stranke oziroma iz pravice do izdaje ugotovitvene odločbe o neobstoju njene ustanovitve, tj. o nepridobitvi pravne osebnosti. Zoper odločbo resornega ministra za notranje zadeve je bilo mogoče vložiti tožbo na upravno sodišče. Tej logiki ni sledilo ustavno sodišče, ki je leta 1983 s svojo sodbo razveljavilo odločbo zveznega avstrijskega ministrstva za notranje zadeve, s katero je slednje opravilo meritorni pravni preizkus vsebine vloge vlagateljev za vpis $v$ register političnih strank z obrazložitvijo, da zakon o političnih strankah ne daje nobenega pooblastila upravi za tovrsten preizkus. Pravna posledica formalnih napak $v$ predloženem statutu politične stranke je lahko kvečjemu nepridobitev pravne osebnosti, medtem ko za vprašanje obstoja politične stranke uprava ni pristojna glede na načelo nekoncesijskega nastanka političnih strank. Vprašanje pravne osebnosti lahko sproži vsakdo, ki je udeležen $\vee$ pravnih poslih s skupino oseb, ki se razglaša za politično stranko, kar sme preizkusiti sleherno sodišče oziroma upravni organ $v$ vsakem primeru posebej.

Sodišča torej incidenter $\vee$ vsakem sporu posebej preizkušajo vprašanje pravne osebnosti političnih strank, kar po izrecni odredbi ustavnega sodišča iz leta 1985 (VtSlg 10 705/1985) velja poleg tega še za vprašanje preizkusa, ali za ustanavljajočo se politično stranko morebiti ne velja prepoved dejavnosti strank nacionalsocialističnega izvora.

Politična združenja se seveda običajno sama ne deklarirajo kot nacionalsocialistična, zato je ugotovitev, da gre res za takšno politično združenje, mogoča le na podlagi izčrpne analize statuta, njegovega programa ter dejanskega delovanja članstva združenja kot kandidata za politično stranko, kot vlagatelja prošnje za registracijo. $V$ tej zvezi lahko koristi tudi vrednostna primerjava $s$ programi in cilji nekdanjih nacionalsocialističnih političnih strank. Že na prvi pogled je mogoče ugotoviti, da lahko sledijo iz take analize dokaj nasprotujoči si zaključki, kar ima za posledico očitek, češ da gre za svojevrsten deficit na področju pravne varnosti. Po mnenju avstrijske teorije je judikatura $\vee$ bistvu povzročila, da je bilo žrtvovano $v$ določeni meri načelo pravne varnosti, zaradi česar se priporoča, da naj bi zakonodajalec izdal poseben zakon, ki bi podrobno 


\section{Mik Strmecki}

\section{Ureditev področja političnih strank v Avstriji}

uredil pogoje za prepoved političnih strank nacionalsocialističnega programskega izvora.

\section{Financiranje političnih strank v Avstriji}

Jedro področnega zakona o političnih strankah pa predstavljajo določbe o financiranju strank iz javnih sredstev (Partei-Gesetz, člen 2).

Pravico do javnega financiranja imajo politične stranke, v kolikor dosežejo več kot en odstotek glasov na volitvah s tem, da dobijo iz javnih virov določeno vsoto sredstev za pokrivanje določenega fiksnega dela svojega javnega delovanja $\vee$ obliki določenega temeljnega zneska ter poleg tega še določen variabilni del, ki je odvisen od uspeha na prejšnjih volitvah.

Variabilni del proračunskih sredstev se med političnimi strankami, kot že rečeno, deli po kriteriju uspeha na volitvah v predhodnem obdobju.

Fiksni del proračunskih sredstev pripada pa le tistim političnim strankam, ki pridobijo vsaj pet poslanskih mandatov $v$ parlamentu ter znaša 140.000 evrov letno (Partei-Gesetz-Novelle - secunda, BGB1996/201).

V parlamentu zastopane politične stranke, imajo od konca osemdesetih let naprej tudi pravico vložitve posebne zahteve $v$ osmih tednih pred volitvami pri kanclerskem uradu za izplačilo določenega zneska za stroške volilne propagande (Parteien-Gesetz-Novelle, BGB 1989/666)

Celoten obseg teh sredstev se izračuna na podlagi števila vseh volilnih upravičencev, medtem ko je delilni ključ določen po merilu uspeha na volitvah. Zanimivo je, da dobijo proračunska sredstva kot nadomestilo stroškov volilne kampanje politične stranke in ne volilne stranke. $V$ praksi to ne povzroča nobenih težav, ker gre dejansko za ene in iste subjekte, kajti volilne stranke $\vee$ Avstriji sestavljajo izključno politične stranke. Sedanja ureditev pa je po mnenju teorije navzlic temu vprašljiva, ker izključuje od financiranja volilne kampanje stranke, za katerimi ne stoji nobena politična stranka.

Analogno zahtevo po povrnitvi stroškov volilne kampanje imajo pravico politične stranke postavljati tudi v zvezi z evropskimi volitvami, odkar se je Avstrija včlanila v Evropsko unijo (Parteien-Gesetz-Novelle - prima, BGB 1996/117). Politične stranke se posredno financirajo tudi prek parlamentarnih frakcij $\vee$ parlamentu (Parlaments-Fraktionen-Finanzierungs-Gesetz BGB, 1985/156), kakor tudi 
iz sredstev namenjenih strankarskemu izobraževalnemu delu v okviru strankarskih akademij (Gesetz ueber die Forderung von Politischen Unterricht und Publizistik, BGB 1984/369). Poleg tega obstajajo številni finančni mehanizmi, s katerimi se pospešuje razvoj političnih strank na deželni ravni itd.

Neposredni viri financiranja avstrijskih političnih strank prinesejo slednjim letno približno 2,3 milijarde evrov $\vee$ njihove strankarske blagajne. Neposredno financiranje pomeni $80 \%$ vseh sredstev, ki dotekajo $v$ blagajne političnih strank (Sickinger, 1997, 228). Veliko bolj nepregledno je posredno proračunsko financiranje, kar velja tudi za razne državne ukrepe namenjene podpori političnim strankam ter njihovemu davčno-pravnemu izenačenju s korporacijami javnega prava (Steuer-Gesetz, BGB, 1975/391). Celo za t.i. strankarske davke so bile leta 1975 uvedene davčne olajšave. Na javni televiziji so predvideni brezplačni termini za politične stranke.

$\checkmark$ primerjavi z drugimi državami je zanimivo, da z ustavnopravnega vidika $v$ Avstriji ni nobenih zadržkov glede proračunskega financiranja političnih strank, vendar pa je ob tem vsekakor zanimivo, da niso bile nikoli vprašljive omejitve tovrstnega načina financiranja. $V$ zadnjem času so se celo nasprotno slišali skorajda absurdni argumenti, ki so prikazovali morebitne omejitve $v$ tej smeri, kot da bi kaj takega konstituiralo nedopusten poseg $\vee$ državno alimentacijsko dolžnost kot obliko specifične regulacije, ki bi se nanašala zgolj na politične stranke in bi bila torej prepovedana po avstrijskem pravnem redu (Sickinger, 1997, 228). V parlamentarnih diskusijah ob sprejetju strankarske zakonodaje $v$ sredini sedemdesetih let je bilo sicer jasno izpostavljeno, da je po avstrijskem pravu dopustno le delno proračunsko financiranje, vendar pa konkretnih omejitev, ki bi bile primerljive z nemško ureditvijo, ni bilo in tudi sedaj ni nikjer zaslediti (Mantl, 1969, 24).

Če bi primerjali Avstrijo in Nemčijo z vidika nemškega načela relativne gornje dopustne meje državnega financiranja, ki ne sme preseči sredstev, ki bi jih stranke pridobile iz drugih virov, potem večina avstrijskih parlamentarnih političnih strank z izjemo Avstrijske socialistične stranke in Avstrijske ljudske stranke tega kriterija ne izpolnjuje, kajti druge stranke $\vee$ povprečju štiri petine vseh svojih finančnih potreb črpajo iz proračuna.

Ob tem se pa že velja zamisliti, ali je takšen delež javnega financiranja še združljiv z načelom svobode političnih strank (Steber, 1999, 13). Ob tolikšni prevladi deleža javnega proračunskega denarja nad deležem iz drugih virov 


\section{Mik Strmecki}

\section{Ureditev področja političnih strank v Avstriji}

pridobljenih sredstev je sporno, ali so politične stranke res neodvisne od države. Poleg tega tudi ne gre več za delno proračunsko financiranje, marveč kar za absolutno prevladujočo obliko njihovega financiranja. Postavlja se vprašanje ali ni političnim strankam spričo tako izdatnega proračunskega financiranja onemogočeno opravljanje njihove temeljne funkcije povezovanja med državo in družbo.

Empirične raziskave so pokazale, da so politične stranke vedno bolj neodvisne od svojega članstva, kar prav gotovo močno odstopa od želenega stanja, ki si ga je zamišljal zakonodajalec $\vee$ času sprejetja današnje avstrijske pravne ureditve na področju financiranja političnih strank, ker je to $\vee$ neposrednem nasprotju z načelom demokratičnosti političnih strank (Mueller, 1992, 181).

\section{Zaključek}

Državnopravna znanost je političnim strankam že sorazmerno kmalu začela pripisovati njihovemu dejanskemu pomenu ustrezno vlogo, kar pa ne moremo trditi glede njihove pozitivno-pravne ureditve, zato njihov pravni položaj ne odseva njihove dejanske vloge v političnem življenju države. Avstrijska ureditev področja političnih strank je imela velik vpliv na ureditev $\vee$ predvojni Jugoslaviji in nasploh $v$ vseh naslednicah bivše habsburške monarhije.

Podobno kot pri nas, tudi $v$ Avstriji politične stranke $\vee$ ustavi niso posebej opredeljene, ker ustavi ne vsebujeta posebnega člena o njih.

Avstrijski ustavni zakon iz leta 1929 je določal nezdružljivost funkcije ustavnega sodnika s funkcijo oziroma zaposlitvijo $v$ politični stranki. Podobno je $v$ slovenski ustavi iz leta 1991 določeno, da funkcija sodnika (133. člen) ter funkcija sodnika ustavnega sodišča (166. člen) nista združljivi s funkcijami v drugih državnih organih, $v$ organih lokalnih skupnosti in $v$ organih političnih strank ter z drugimi funkcijami in dejavnostmi, za katere to določa zakon.

Zaostanek avstrijske pozitivno-pravne ureditve področja političnih strank je mogoče pripisati tudi anahronističnemu ločevanju političnih in volilnih strank, ki obstajajo samo v času volilne kampanje. Ta zastarela koncepcija izhaja iz predstave, da še sedaj obstaja tip politične stranke, ki še ni organizacija masovnega značaja. 


\section{Mik Strmecki
Ureditev področja političnih strank v Avstriji}

Avstrijski zakon o političnih strankah ne vsebuje definicije politične stranke in tudi nima nobene določbe, ki bi se nanašala na notranjo organizacijo politične stranke.

V primerjavi z nemško ureditvijo, avstrijski zakon o političnih strankah ne omenja nobenih nalog, ki bi jih pravni red strankam nalagal zaradi zagotavljanja znotrajstrankarske demokracije.

Razlika med nemško in avstrijsko ureditvijo izhaja iz razlike $v$ samem izhodišču obeh tipov demokracij. Nemški model izhaja, zaradi tragičnih zgodovinskih izkušenj, iz tipa vrednostno angažirane demokracije, ki je pripravljena braniti svojo vrednostno substanco, medtem ko avstrijski model demokracije izhaja iz tipa vrednostno nevtralne demokracije, zavezane zgolj demokratični proceduri, ki $v$ načelu dovoljuje odpravo demokracije po demokratični poti.

Ustavna presoja okoliščine, da je večina avstrijskih političnih strank za svoje preživetje tako usodno odvisna od proračuna (80 \%) se ne more ob tem izogniti globljemu razmisleku o pravni relevantnosti z ustavo zajamčenega načela varstva večstrankarske politične ureditve. Navzlic temu pa je težko upravičiti s temi argumenti tolikšen obseg proračunskega deleža pri financiranju političnih strank.

Osrednji problem financiranja političnih strank $\vee$ Avstriji in političnega financiranja nasploh je $v$ tem, da politične stranke same odločajo o višini njim dodeljenih finančnih sredstev ob priliki odločanja njihovih poslancev o državnem proračunu, s čimer je tovrstno odločanje $v$ proceduralnem smislu odtegnjeno učinkovitemu nadzoru javnosti.

Mik Strmecki je doktor pravnih znanosti. Po diplomi je bil kot pripravnik zaposlen na Ministrstvu za pravosodje in kasneje na Višjem sodišču v Ljubljani. Leta 1981 je opravil pravosodni izpit. Po krajši zaposlitvi v Narodni in univerzitetni knjižnici v Ljubljani, se je najprej kot asistent za javno upravo zaposlil na tedanji Višji upravni šoli, nato pa v letih 1992 do 2003 kot višji predavatelj za javno upravo ter predaval upravno pravo. Leta 2003 je postal docent za javno upravo na Fakulteti za upravo Univerze v Ljubljani. Je avtor dveh učbenikov in praktikuma s področja splošnega in posebnega dela upravnega prava. 


\section{Mik Strmecki \\ Ureditev področja političnih strank v Avstriji}

\section{Literatura in viri}

- Kelsen, Hans.: (1929): Vom Wesen und Wert der Demokratie, 2.izd., J.C.B. MohrVerlag, Tuebingen.

- Kostelka, Peter (1983): Politische Parteien in der oesterreichischen Staatsordnung, v: Fest-Schrift Floretta Verlag, Wien.

- Kraus, Herbert (1929): Die Politische Partei als Rechtssubjekt: Politische Partei und Wahl-Partei, članek v: Juristen-Blatt, Wien.

- Mantl, Andreas: (1969): Staatliche Parteienfinanzierung und Bundesverfassung, članek, OJZ, Wien.

- Mueller, Walther (1992): Das Parteiensystem: Dachs et al. (ur.): Handbuch des politischen Systems Oesterreichs, Domus Verlag, Wien.

- Oehlinger, Theo (1993): Der Klub des Liberalen Forums, JRP, Wien.

- Raschauer, Bernhard (1986): Die Rechtstellung politischer Parteien, v: Pelinka/Plasser (ur.), Das Oesterreichische Parteiensystem, Domus Verlag, Wien.

- $\quad$ Schambeck, Herbert (1991): Politische Parteien und oestereichische Staats-RechtsOrdnung, v: FS Walter, Domus Verlag, Wien.

- $\quad$ Sickinger, Hubert (1997): Politik-Finanzierung in Oesterreich, Handbuch, Huber Verlag, Wien.

- Song, Seug-Yun (1996): Politische Parteien und Verbände in der VerfassungsRechts- Lehre der Weimarer Republik, C.F. Mueller Verlag, Heidelberg.

- Steber, Manfred (1999): Die Parteien-Institution in Oesterreich, Institut für ParteienRecht, Hagen.

- Deklaracija o neodvisnosti, SA G BI. 1945/čl. 1

- $\quad$ Gesetz über die Forderung von politischen Unterricht und Publizität, BGB 1984/369.

- $\quad$ Parteien-Gesetz BGB 1975/13.

- $\quad$ Parteien-Gesetz-Novelle BGB 1989/666.

- $\quad$ Parteien-Gesetz-Novelle-prima BGB 1996/117.

- Parteien-Gesetz-Novelle- secunda BGB 1996/201.

- $\quad$ Steuer-Gesetz BGB 1975/391.

- $\quad$ Vereins-Gesetz 1867/134.

- Vereins-Gesetz-Novelle BGB 1984/251. 


\section{SUMMARY \\ THE REGULATION OF POLITICAL PARTIES IN AUSTRIA}

The article presents an extensive analysis of the development of the political party system in Austria from its beginnings to the present. It also describes both the traumatic interwar period and the relatively calm period following the aftermath of the Nazi destruction of the Austrian Rechtstaat (constitutional state) after the 1938 Anschluss.

The treatment of political parties in Austrian law is not adequate. The actual role of political parties vastly transcends the importance that they seem to be given by the legal system. Austrian legal conceptions regarding political parties had an important bearing on pre-war Yugoslav legal thought and also on that of other successor states of the Habsburg Empire. There is a striking similarity between the Austrian and Slovenian Constitutions - neither of them mentions political parties. They only mention the incompatibility of executing a judicial function, especially that of a constitutional court judge, with political party membership.

The situation is accerbated by the fact that besides political parties the Austrian legal doctrine still recognises voting parties which are activated only during electoral campaigns. This conception is nowadays viewed as anachronistic because it implies the 19th century conception of a political party when political parties were not yet mass organisations. Moreover, the Austrian statute law on political parties does not give a definition of a political party nor does it contain any paragraph on the internal organisation of political parties. Unlike in the German law, in the Austrian statute law on political parties these are not required to guarantee internal democratic practices by laying them down in their internal organisational rules.

The freedom of association should not be subject to restrictions, barring cases where the state authority has formally proven and defined legal grounds to intervene in order to protect the public interest. The state is specifically empowered to enforce such a legal regime to provide a level and equitable distribution of opportunity for all legitimate participants. The state has to preserve the public interest while guaranteeing a free, democratic and republican political and legal order. The state has to preclude totalitarian, party-monopolistic or just plain plutocratic tendenci- 
Mik Strmecki

Ureditev področja političnih strank v Avstriji

es. What is dreaded is a system where money talks, and which is nowadays conventionally dubbed the syndrome of the so-called "political market».

In case of Austria it is important to point out that the structures of patronage in some spheres did not die out with feudalism's abrupt departure in 1848 (after the so-called March Revolution in Vienna). What died out with feudalism was open, often naively unhidden patronage, undoubtedly attributable to the simplistic circumstances of a still well-functioning feudal overlordship system with its huge potential for patronage in its heyday. However, the dark capacity of human nature to be able to corrupt each and every institution it ever lay hands on did not die out, the exfeudal patronage was merely transposed to the emergent political system. This led to the omnipresence of a clearly outdated system of emergency powers regulations, which were, to make matters worse, abundantly utilised in the wake of the malaise following the Armistice of 1918.

From a purely legal-technical standpoint the problem of political party politics is really centred around two main issues. The first issue is the way candidates are nominated. When political parties have the exclusive right to nominate candidates for elections, non-party candidates are by law considered non-starters and are unable to enter the political contest on their own. It is crystal clear that such a system, by its very nature, begets a sort of unsavoury dependency of each and everyone who wishes to pursue his or her carreer in politics.

The second issue is the political party privilege according to which only the Constitutional Court has the right to rule a political party out of its existence on the grounds that it harbours totalitarian tendencies of national-socialist provenance. Prior to 1983 , the Minister of the Interior as the registering authority had the right to decide whether a party could be registered or not, not only on procedural grounds, but also on merits and grounds of a non-procedural nature. In 1983, the Constitutional Court denied the Minister of the Interior the right to rule on merits in such cases, namely to probe whether a registering entity vying for party status should be allowed to register as a political party or not on the grounds that it harbours national-socialist totalitarian tendencies manifested in the party programme. Prior to 1983 , the aggrieved party had the right to judicial recourse to the Administrative Court. Since 1983 the only competent 
authority before which it is possible to instigate such proceedings is the Constitutional Court.

Last but not least, the issue of financing. The mode of financing of political parties along with the financing of candidates running for them is not something one would give low priority to. The legal system cannot afford to carelessly relegate those important issues to an already overwhelming private sector not at all harnessed by the Rechtstaat in these postmodern times when state meddling is considered ill-found and out of step with the new Zeitgeist; at the same time we have to bear in mind that also excessive budget subsidies to political parties may be counter-productive. Many prominent Austrian scholars from the field of political party financing are alarmed and are pointing their fingers at the excessively high proportion of budgetary financing of Austrian political parties, which are financed from the state budget in excess of $80 \%$ of their financial needs.

In conclusion, the most striking difference between the German and Austrian political party systems from the standpoint of legal regulation stems from the different types of democracy the two countries are based on. Germany opted for a type of values-oriented democratic system of government that is prepared to defend the values enshrined in the state constitution, while Austria opted for a formalistic type of democracy based predominantly on democratic procedure, which does not vouch for the prevention of the demise of democracy by democratic means. Germany learned a lesson from her pre-war mistakes and made the necessary changes in her legal system to thwart in advance a possible reemergence of dictatorial rule. 